\title{
Antiviral effect of prolonged intermittent lymphoblastoid alpha interferon treatment in chronic hepatitis B
}

H L A Janssen, L Berk, S W Schalm, R A Heijtink, G Hess, S Rossol,

K-H Meyer zum Buschenfelde, R A F M Chamuleau, P L M Jansen, H W Reesink, B Meyer, C Beglinger, J W den Ouden-Muller, M de Jong, C J J Mulder

Department of Internal Medicine II, University Hospital Dijkzigt, Rotterdam, The Netherlands

H L A Janssen

L Berk

S W Schalm

Department of Virology, Erasmus University, Rotterdam, The

Netherlands

R A Heijtink

I Medizinische Klinik und Poliklinik, Klinikum der Johannes Gutenberg

Universitat, Mainz,

Germany

G Hess

S Rossol

K-H Meyer zum

Buschenfelde

Department of Internal Medicine G-2, Academic

Medical Centre,

Amsterdam, The

Netherlands

R A F M Chamuleau

P L M Jansen

H W Reesink

Division of

Gastroenterology,

University Hospital

Basel, Switzerland

B Meyer

C Beglinger

Department of Internal Medicine, St Franciscus Hospital Rotterdam, The Netherlands

J W den Ouden-Muller

$M$ de Jong

Department of Internal Medicine, Rijnstate Hospital Arnhem, The Netherlands

C J J Mulder

Correspondence to:

Prof dr S W Schalm, Dept of Internal Medicine II, Room Ca

326, University Hospital

Dijkzigt, Dr Molewaterplein

Netherlands.

Accepted for publication

4 November 1991
Abstract

In a European multicentre study $\mathbf{4 0}$ patients with $\mathrm{HBeAg}$ positive chronic hepatitis $B$ virus (HBV) infection were treated with 5 mega units of lymphoblastoid $\alpha$-interferon daily according to the following regimen: a four week primer course, four weeks of rest and a second course lasting 16 to 30 weeks. After 52 weeks of follow up, a response (HBeAg seroconversion and HBV-DNA negativity) was observed in 22 patients (55\%). HBsAg seroconversion occurred in five patients $(12 \cdot 5 \%)$. One patient exhibited a relapse for serum $\mathrm{HBeAg}$ and HBV-DNA after cessation of treatment. According to a response prediction model, the observed response rate was not related to the selection of patients likely to respond. The initial interferon course induced a reduction of the serum HBV-DNA and HBeAg levels of $87 \%$ and $18 \%$, respectively, leading to a significantly lower level of viral replication activity at the start of the second longterm course compared with baseline. After 24 weeks of follow up (week 16 of the second course), $19(48 \%)$ patients exhibited a response, 13 (32\%) a partial response (HBeAg $<50 \%$ of initial level or HBV-DNA negative) and 8 $(20 \%)$ no response. For eight of the 13 partial responders treatment was stopped at week 24 and viral replication rebounded to pretreatment values. In the last five partial responders prolongation of therapy up to week 38 led to a definite response and $\mathrm{HBsAg}$ seroconversion in three of the five patients. The results of this study suggest that a short primer course and prolongation of therapy may help to enhance the response rate of $\alpha$-interferon therapy for chronic hepatitis type $B$.

(Gut 1992; 33: 1094-1098)

In patients with chronic hepatitis B virus (HBV) infection active viral replication is usually associated with continuing inflammatory activity and progression of liver disease. Transition to viral latency, as indicated by hepatitis $\mathrm{B}$ e antigen ( $\mathrm{HBeAg}$ ) seroconversion and clearance of serum HBV-DNA, is accompanied by biochemical and histological regression of liver disease activity. ${ }^{1-3}$ With the availability of $\alpha$-interferon, termination of the viral replicating phase can be induced in about 30 to $40 \%$ of the patients. ${ }^{+6}$ Usually interferon is given in a single continuous course.

From a pilot study comparing the antiviral effect of interferon, acyclovir and a combination of interferon and acyclovir, it was concluded that combination therapy appears to be a highly promising treatment for chronic hepatitis B. ${ }^{7}$ As more recent controlled studies have shown that acyclovir does not enhance the therapeutic effect of interferon alone, ${ }^{8}$ the results of the pilot study could also be interpreted as indicating that a second course of interferon after short term primer interferon therapy is more effective than a single course. Therefore we investigated the effect of intermittent interferon treatment on termination of herpatitis B viral replication, measured by $\mathrm{HBeAg}$ seroconversion and $\mathrm{HBV}$ DNA clearance from serum.

\section{Methods}

\section{PATIENTS AND TREATMENT}

Forty four patients from six European hospitals were enrolled in the study after central evaluation of their eligibility. At entry all patients had been seropositive for hepatitis B surface antigen (HBsAg) and HBeAg for at least six months. Histological evidence of chronic hepatitis was present in all patients who underwent a liver biopsy $(n=43)$. Patients were excluded on grounds of the following criteria: age under 18 or over 70 years; presence of hepatitis delta antibodies in serum; antiviral or immune modulatory therapies in the preceding six months; history or presence of decompensated liver disease (ascites, encephalopathy, variceal haemorrhage); pregnancy; impaired immunity, including seropositivity for human immunodeficiency virus with $\mathrm{T} 4$ cells $<400 / \mathrm{mm}^{3}$; inadequate levels of platelets $\left(<70 \times 10^{9} / 1\right)$ or white blood cells $\left(<3 \times 10^{9} / 1\right)$; recent drug or alcohol abuse; presence of significant other disease that might interfere with the study. The study was approved by the ethical committees of all participating centres and written informed consent was obtained from each patient who entered the study.

Lymphoblastoid $\alpha$-IFN (Wellferon, Wellcome, Beckenham, UK) was given at a dose of 5 mega units daily according to the following regimen: a four week primer course, a four week rest period and a second interferon course lasting 16 weeks; for five patients from Rotterdam the duration of the second course was prolonged up to 30 weeks. Patients were taught to selfadminister interferon subcutaneously. During the first four days of interferon therapy indomethacin or paracetamol was given to suppress early side effects. Interferon treatment was discontinued in the event of absence of $\mathrm{HBeAg}$ on 
two successive occasions or intolerable side effects. Follow up began at the start of therapy and was continued for 52 weeks.

\section{CLINICAL AND LABORATORY EVALUATION}

Patients were seen, and if indicated examined, at the outpatient clinic every two to four weeks during treatment and every four to eight weeks during the period thereafter. Laboratory assessment was performed every two weeks during the treatment period and every four to six weeks after discontinuation of therapy. On these occasions routine haematological studies were performed and serum markers of viral replication (HBeAg and HBV-DNA) and aspartate aminotransferase activity were measured. Every three months additional biochemical and virological measurements including the prothrombin time and the levels of alanine aminotransferase, albumin, bilirubin, $\mathrm{HBsAg}$, and antibodies against $\mathrm{HBs} \mathrm{Ag}$ as well as $\mathrm{HBeAg}$ were performed. Liver biopsies were taken within six months of entry to the study for histological assessment.

All virological parameters were determined centrally at the Rotterdam hepatitis laboratory. HBsAg was assessed using a commercial radioimmunoassay kit (Abbott, Ill, USA). HBeAg was measured quantitatively using a radioimmunoassay (Abbott, Ill, USA). For quantification a $P / N$ ratio (counts of patient sample/ counts of negative control sample) was determined for each patient in a fixed serum dilution. $\mathrm{HBeAg}$ seroconversion was defined as a $\mathrm{P} / \mathrm{N}$ ratio under $2 \cdot 1$ for undiluted serum from two consecutive blood samples. HBV-DNA was measured by a liquid hybridisation assay using an iodine 125 probe (Abbott, Ill, USA). Antibodies to hepatitis $\mathrm{C}$ virus were determined, retrospectively, by enzyme immunoassay (Abbott, Ill, USA); positive results were confirmed by a recombinant immunoblot assay

Patients characteristics at entry into the study

\begin{tabular}{|c|c|c|c|}
\hline & $\begin{array}{l}\text { Treatment group } \\
(n=40)\end{array}$ & $\begin{array}{l}\text { Response } \\
(n=22)\end{array}$ & $\begin{array}{l}\text { Non-response } \\
(n=18)\end{array}$ \\
\hline $\operatorname{Age}^{\star}(y r)$ & $38 \cdot 5(18-67)$ & $42(27-67)$ & $37(18-56)$ \\
\hline Male/female & $32 / 8$ & $17 / 5$ & $15 / 3$ \\
\hline Homo/heterosexual & $9 / 31$ & $3 / 19$ & $6 / 12$ \\
\hline HBsAg duration` (mo) & $27(6-132)$ & $14(6-132)$ & $33(12-96)$ \\
\hline History acute hepatitis & 2 & & \\
\hline \multicolumn{4}{|l|}{ Histology: } \\
\hline $\mathrm{CPH}$ & 8 & 2 & 6 \\
\hline CAH & 20 & 12 & 8 \\
\hline Cirrhosis & 11 & 8 & 3 \\
\hline Anti-HCV positive & 1 & 1 & 0 \\
\hline \multicolumn{4}{|l|}{ HIV-status: } \\
\hline Negative & 38 & 21 & 17 \\
\hline Unknown & 2 & 1 & 1 \\
\hline $\mathbf{H B e A g}{ }^{\star}(\mathrm{P} / \mathrm{N}$ ratio $)$ & $12 \cdot 4(2 \cdot 2-18 \cdot 8)$ & $13 \cdot 4(2 \cdot 5-18 \cdot 8)$ & $11 \cdot 9(2 \cdot 2-16 \cdot 4)$ \\
\hline $\begin{array}{l}\text { HBV-DNA }{ }^{\star}(\mathrm{pg} / \mathrm{ml}) \\
\text { HBV-DNA }\end{array}$ & $102(1-1001)$ & $79(1-730)$ & $127 \cdot 5(3-1001)$ \\
\hline $\begin{array}{l}\mathrm{HBV}-\mathrm{DNA} \\
<50 \mathrm{pg} / \mathrm{ml}\end{array}$ & & 8 & HBV-DNA \\
\hline $51-100$ & 9 & 6 & 3 \\
\hline $101-300$ & 13 & 5 & 8 \\
\hline$>300$ & & & \\
\hline $\operatorname{AST}^{\star}(\mathrm{U} / \mathrm{l})$ & $57 \cdot 5(15-475)$ & $66 \cdot 5(15-475)$ & $51 \cdot 5(16-113)$ \\
\hline \multicolumn{4}{|l|}{ AST } \\
\hline $31-60$ & 14 & $\begin{array}{l}3 \\
7\end{array}$ & $\begin{array}{l}4 \\
7\end{array}$ \\
\hline $61-100$ & 11 & 5 & 6 \\
\hline$>100$ & 8 & 7 & 1 \\
\hline
\end{tabular}

$\star$ Median (range).

AST normal < 30 U/l; HBV-DNA cut-off: $1.5 \mathrm{pg} / \mathrm{ml} ; \mathrm{HBeAg}$ cut-off: P/N ratio $2 \cdot 1$.

AST $=$ aspartate aminotransferase.
(Ortho Diagnostics Systems, USA). Routine serobiochemical tests were performed using automated techniques (Coulter, Technicon, NY, USA).

The criteria for response to treatment were: $\mathrm{HBeAg}$ seroconversion and serum HBV-DNA negativity. The criteria for partial response to treatment were: a decrease in serum $\mathrm{HBeAg}$ of $50 \%$ or more of the initial level or serum HBV-DNA negativity with sustained $\mathrm{HBeAg}$ positivity after 24 weeks of follow up.

To analyse whether the response rate was related to treatment modification or selection of patients, the actual response was compared with a predicted response that was obtained with a response model developed by Brook et al. ${ }^{9}$ The prediction of response was based on pretreatment aspartate aminotransferase levels, the presence of a history of acute hepatitis and HIV-antibody status.

\section{STATISTICAL ANALYSIS}

Differences in dichotomous and other discrete variables were analysed by the Fisher exact and $\chi^{2}$ tests, respectively. For continuous variables medians were used because the results lacked normal distribution. The two sample Wilcoxon's rank sum test was used to analyse unpaired observations and the Wilcoxon's signed rank test to analyse paired observations.

\section{Results}

Four of the 44 patients were withdrawn from the study. Two patients were found to be $\mathrm{HBeAg}$ negative at the start or within one week of treatment while pre-entry assessments were positive. Two patients were lost to follow up: one withdrew from treatment after two weeks for reasons unrelated to the study protocol and one patient failed to comply with the protocol after cessation of therapy.

Patient characteristics at entry are shown in the Table. Of the 40 patients who were analysed, one was serum HBV-DNA negative on entry to the study.

\section{RESPONSE}

A response to treatment $(\mathrm{HBeAg}$ seroconversion and serum HBV-DNA negativity) was observed in 22 of the 40 patients $(55 \%$; $95 \%$ confidence interval (CI) $40-70 \%)$. Five patients $(12 \cdot 5 \%$; 95\% CI 4-27\%) became negative for $\mathrm{HBsAg}$. Sustained aspartate aminotransferase normalisation occurred in 16 of 19 responders with raised aspartate aminotransferase levels on entry to the study. Figure 1 shows the timing of elimination of viral parameters and sustained aspartate aminotransferase normalisation in the response group. All but one patient exhibited the response while on interferon therapy. A characteristic sequence in clearance of $\mathrm{HBV}-\mathrm{DNA}$ and $\mathrm{HBeAg}$ and then normalisation of aspartate aminotransferase levels was observed for the majority of the responders. One responder showed a relapse for serum $\mathrm{HBeAg}, \mathrm{HBV}-\mathrm{DNA}$ and aspartate aminotransferase 20 weeks after cessation of therapy. Of the 18 non-responders, five exhibited normal- 


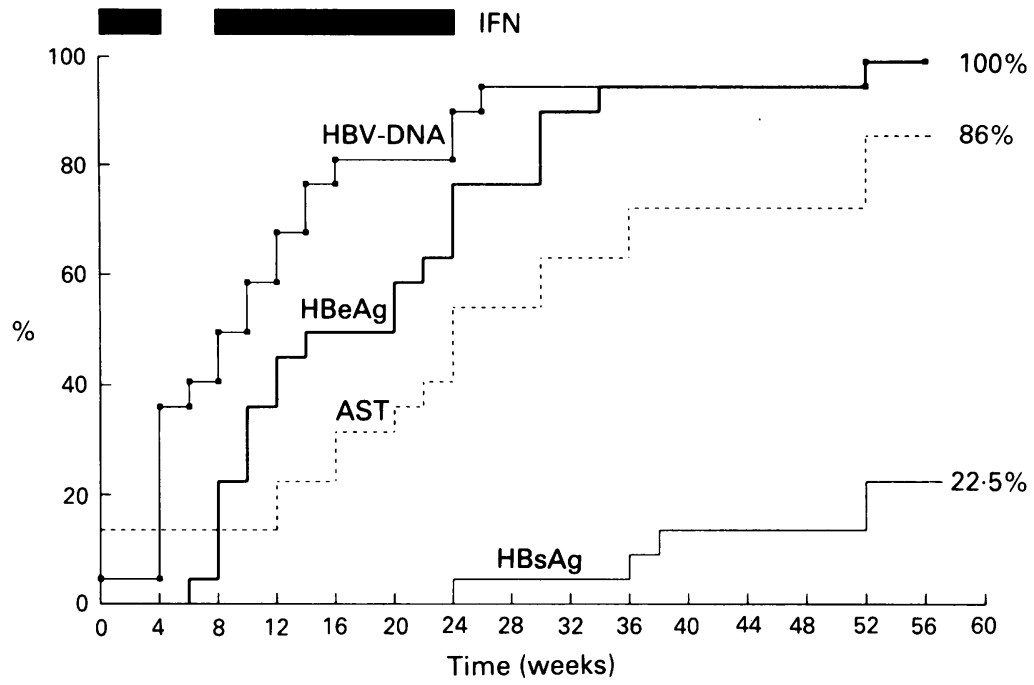

Figure 1: Cumulative percentage of clearance of serum HBV-DNA, HBeAg seroconversion, normalisation of serum aspartate aminotransferase and HBsAg seroconversion for patients who responded to therapy $(n=22)$.

isation of aspartate aminotransferase levels and six became, briefly, serum HBV-DNA negative.

Differences in characteristics between responders and non-responders are shown in the Table. The pretreatment serum HBV-DNA level was lower and the aspartate aminotransferase level higher in the response group. Also the duration of $\mathrm{HBsAg}$ positivity was shorter and the presence of cirrhosis was more prominent in responders. No statistical difference between responders and non-responders, however, was found for any of these parameters.

According to the Brook model, a response was predicted for 14 of the 40 patients $(35 \% ; 95 \% \mathrm{CI}$ $20-50 \%$ ), with a positive predictive value of $79 \%$ and a negative predictive value of $58 \%$. Compared with this prediction the actual response rate of $55 \%$ was significantly higher $(p=0 \cdot 03)$.

\section{INTERMITTENT TREATMENT}

Changes in serum aspartate aminotransferase, HBV-DNA and HBeAg values are shown in Figure 2. The primer interferon course reduced HBV-DNA and HBeAg levels by 87 and $18 \%$, respectively, but the decrease did not continue

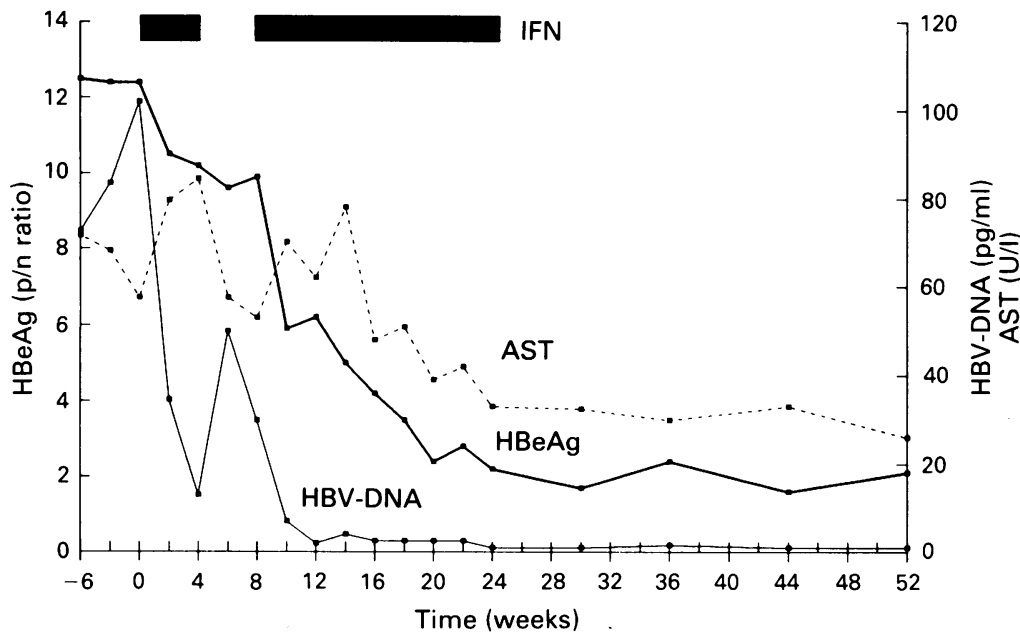

Figure 2: Median levels of $H B e A g, H B V-D N A$ and aspartate aminotransferase in serum $(n=40)$ during the four weeks without therapy. Nevertheless, at the start of the second interferon course, the serum HBeAg and HBV-DNA levels were significantly lower compared with baseline values. No difference was found in the aspartate aminotransferase levels at the start of the two courses; however, both courses seemed to induce a peak of aspartate aminotransferase values that often preceeds a response to therapy.

\section{PROLONGED TREATMENT}

After 24 weeks of follow up (week 16 of the second course), 19 (48\%; 95\% CI 32-63\%) patients exhibited a response, $13(32 \% ; 95 \% \mathrm{CI}$ $18-47 \%)$ a partial response and eight $(20 \% ; 95 \%$ CI 8-32\%) a definite non-response. For eight of the 13 partial responders, treatment was stopped at 24 weeks. After cessation of therapy the serum HBeAg and HBV-DNA levels in these patients rebounded to baseline levels (Fig 3). For the last five partial responders interferon therapy was prolonged up to week 38 . Three of these five exhibited an additional response during prolonged therapy (Fig 4), and all three showed HBsAg seroconversion shortly after the response.

\section{SIDE EFFECTS OF INTERFERON}

During the first week of the initial interferon course, a transient flu like syndrome with fever, chills and myalgia was observed in nearly all of the patients. At the beginning of the second course, the majority again reported these symptoms but to a lesser intensity. The predominant adverse effects after the first days of therapy were fatigue $(73 \%)$, myalgia $(60 \%)$, anorexia $(43 \%)$, irritability $(30 \%)$, and hair loss $(15 \%)$. Two patients developed an acute psychosis: the first, who had just finished therapy, required intensive psychiatric care for two weeks; the second, who had been treated with interferon for three weeks, fell and fractured the acetabulum. Another patient had a generalised seizure after four and 11 weeks; he was put on anticonvulsive medication and interferon was tapered to 1.25 mega units daily. Side effects led to dose reduction in 11 subjects $(28 \%)$. The reasons for dose reduction were fatigue in six cases, thrombocytopenia in two, neurotoxicity in two, and leukopenia in one. Four $(36 \%)$ of these 11 patients exhibited a response.

\section{Discussion}

In recent years several strategies have been tested to enhance the efficacy of interferon therapy for chronic hepatitis B. None of these strategies, including additional therapy with agents such as gamma interferon, prednisone, acyclovir or adeninide arabinoside ${ }^{510-12}$; has proved to be more beneficial than a standard interferon course of 12-16 weeks.

In this uncontrolled pilot study we investigated the effect of prolonged intermittent interferon therapy in 40 patients. Fifty five per cent of the patients responded with $\mathrm{HBeAg}$ seroconversion and loss of serum HBV-DNA. HBsAg seroconversion occurred in $12.5 \%$ of all treated 


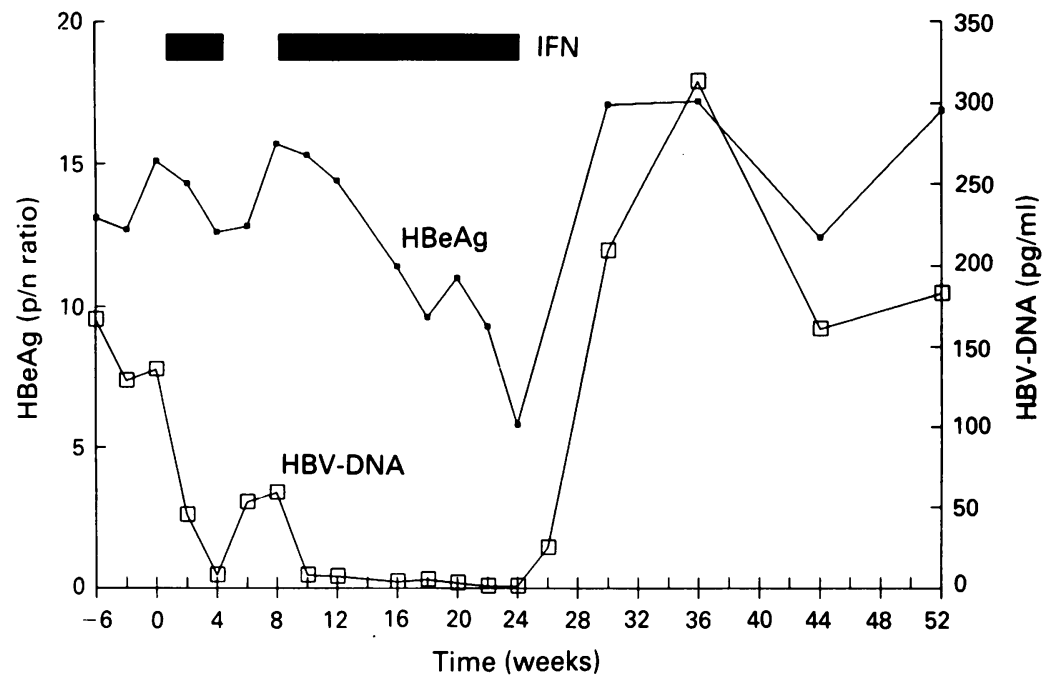

Figure 3: Serum HBeAg and HBV-DNA levels in a partial responder treated until 24 weeks (protocol therapy). patients and in almost $25 \%$ of those who responded. A majority of the responders showed a characteristic sequence in loss of serum HBVDNA and $\mathrm{HBeAg}$ followed by normalisation of the aspartate aminotransferase value. $\mathrm{HBeAg}$ seroconversion was often heralded by a rise in transaminase activity and loss of HBV-DNA. In six patients, however, HBV-DNA disappeared from the serum but quickly reappeared after discontinuation of therapy, indicating that persistent absence of $\mathrm{HBeAg}$ is the best indicator for termination of the viral replicating phase.

Although several differences in pretreatment characteristics of responders versus nonresponders were observed, none of them was found to be significant. The predicted response rate, based on a combination of pretreatment factors, ${ }^{9}$ was significantly lower $(35 \%)$ than the actual response rate $(55 \%)$. This result suggests that the high response rate was not caused by selection of patients likely to respond but by the treatment modification.

It is difficult to determine the contribution of intermittent therapy to the high response rate obtained in this uncontrolled study. The rationale for the initial four week course was to

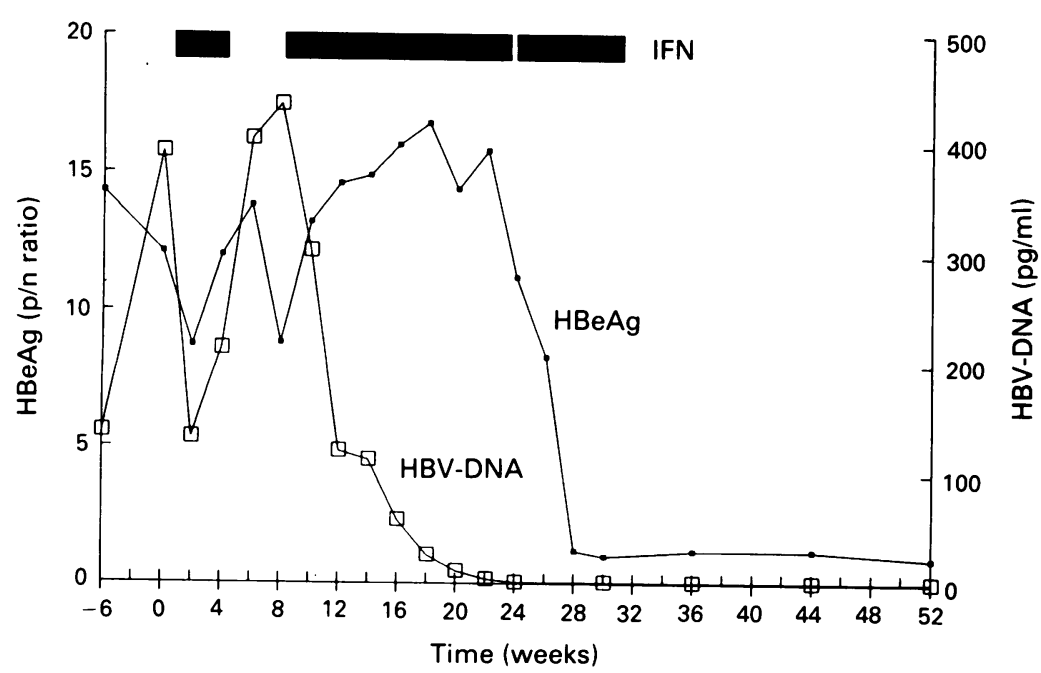

Figure 4: Serum HBeAg and HBV-DNA levels in a partial responder treated until 32 weeks (prolonged therapy) who exhibited an additional response. decrease viral replication and increase inflammatory activity before the start of the longterm course, thereby enhancing the possibility of response to therapy. At the start of the second interferon course, viral replication, as monitored by serum HBV-DNA and HBeAg levels, was indeed significantly lower compared to baseline values. In addition, both interferon courses induced transient rises in aminotransferase levels. Therefore both courses could have induced a response in some patients and the double transaminase peak could thus be indicative of early and late responders. These interesting observations certainly justify further evaluation of intermittent treatment in a controlled setting.

Close on line monitoring of the effects of interferon on viral replication revealed that in several patients $\mathrm{HBeAg}$ and $\mathrm{HBV}-\mathrm{DNA}$ serum values decreased continuously and were almost negative when treatment was stopped (week 24) at which point a relapse occurred. Therefore, we decided to offer prolonged treatment to the remaining patients who approximated a response at the end of the scheduled therapy (partial response). For three of the five partial responders this approach led to a definite response and subsequently to $\mathrm{HBsAg}$ seroconversion. Of the two patients who did not respond to prolonged treatment one had extremely high initial serum HBV-DNA levels $(>1000 \mathrm{pg} / \mathrm{ml}$ ), while both patients had near normal aspartate aminotransferase levels at entry. These features, low serum aminotransferase and high HBV-DNA levels, have been suggested to interfere with the response to interferon treatment. ${ }^{45913}$ Our findings indicate that prolonging interferon therapy may increase the $\mathrm{HBeAg}$ and $\mathrm{HBsAg}$ seroconversion rates in the subset of patients that partially respond to standard interferon treatment. To select patients eligible for treatment prolongation, close monitoring of quantified levels of $\mathrm{HBeAg}$ and HBV-DNA is essential.

From the literature it is not clear whether prolongation of therapy beyond four months yields a higher response rate. Prolonged therapy can further decrease HBV replication which may trigger the cullular immune response leading to the hepatocytotoxic reaction that eradicates viral replication. ${ }^{14}$ In most parts of the world the standard duration of therapy is considered to be 12-16 weeks, usually leading to a response rate of $30-40 \%,{ }^{+615}$. Interferon has been given for 24 weeks or longer in a few, mainly Mediterranean, studies (response rates $26 \%$ to $70 \%$ ). ${ }^{16-18} \mathrm{~A}$ controlled trial comparing 12 to 24 weeks of treatment failed to show any beneficial effect of the prolonged therapy. ${ }^{19}$ The outcome of that study, however, was markedly influenced by a lack of compliance (eight of the 20 patients withdrew from the longer course). In the present study none of the patients had to withdraw from therapy because of side effects, irrespective of the length of treatment. Both the intermittent treatment schedule and intensive patient monitoring with mental support may have contributed to the good compliance. Nevertheless, three of our patients had major neuropsychiatric side effects (psychosis, seizures). Future studies might elucidate whether these serious side 
effects relate to dose and/or duration of the interferon treatment.

In summary, prolonged intermittent interferon therapy resulted in $\mathrm{HBeAg}$ seroconversion and serum HBV-DNA negativity in $55 \%$ and in HBsAg seroconversion in $12 \cdot 5 \%$ of the patients. The high rate of induced viral latency was probably related first to the short initial interferon course that reduced viral replication significantly before the start of the second longterm course and second to prolongation of therapy in partial responders which induced additional $\mathrm{HBeAg}$ seroconversion.

The study was supported by a grant from Wellcome Research Laboratories, Beckenham, Kent, United Kingdom.

1 Realdi G, Alberti A, Rugge M, Bortolotti F, Rigoli AM, Tremolada $F$, et al. Seroconversion from $\mathrm{HBe}$ antigen to antiHBe in chronic hepatitis B virus infection. Gastroenterology 1980; 79: 195-9.

2 Hoofnagle JH, Dusheiko GM, Seef LB, Jones EA, Waggoner JG, Bales ZB. Seroconversion from HBe antigen to antibody in chronic type B hepatitis. Ann Intern Med 1981; 94: 744-8.

in chronic type B hepatitis. Ann Intern Med 1981; 94: 744-8.
3 Fattovich G, Rugge M, Brollo L, Pontisso P, Noventa F, Fattovich G, Rugge $M$, Brollo $L$, Pontisso $P$, Noventa $F$,
Guido $M$, et al. Clinical virologic and histologic outcome Guido $M$, et al. Clinical virologic and histologic outcome
following seroconversion from $\mathrm{HBeAg}$ to antiHBe in chronic following seroconversion from $\mathrm{HBeAg}$ to antiH

hepatitis type B. Hepatology 1986; 6: 167-72.
4 Hoofnagle JH, Peters M, Mullen KD, Jones DB, Rustgi V, Di Bisceglie A, et al. Randomized controlled trial of recombinant human $\alpha$-interferon in patients with chronic hepatitis B. Gastroenterology 1988; 95: 1318-25.

5 Perillo RP, Schiff ER, Davis GL, Bodenheimer HC Jr, Lindsay K, Payne J, et al. A randomized controlled trial of interferon alfa-2b alone and after prednisone withdrawal for the treatment of chronic hepatitis B. N Engl F Med 1990; 323: 295-301.

6 Brook MG, Chan G, Yap I, Karayiannis P, Lever AM, Jacyna $M$, et al. Randomised controlled trial lf lymphoblasoid interferon alfa in Europid men with chronic hepatitis B virus interferon alfa in Europid men with
infection. $B M 7$ 1989; 299: 652-6.
7 Schalm SW, Van Buuren HR, Heijtink RA, De Man RA Acyclovir enhances the antiviral effect of interferon in chronic hepatitis type B. Lancet 1985; ii: 358-60.

8 Berk L, Schalm SW, De Man RA, Heijtink RA, Berthelot P, et al. Failure of acyclovir to enhance the antiviral effect of alpha lymphoblastoid interferon on $\mathrm{HBe}$-seroconversion in chronc hepatitis B. A multi-centre randomized controlled trial. F Hepatol 1992; 14: 305-9.

9 Brook MG, Karayiannis P, Thomas HC. Which patients with chronic hepatitis $B$ virus infection will respond to alphainterferon therapy? A statistical analysis of predictive factors. Hepatology $1989 ; 10: 761-3$

10 Garcia G, Smith CI, Weissberg JI, Eisenberg M, Bissett J, et al. Adenide arabinoside monophosphate (vidarabine phosphate) in combination with human leukocyte inarabine phosphate) 107: 278-85.

11 Di Bisceglie AM, Rustgi VK, Kassianides C Lisken-Melman M, Park Y, Waggoner JG, et al. Therapy of chronic hepatitis $B$ with recombinant human alpha and gamma interferon. Hepatology 1990; 2: 266-70.

12 Hoofnagle JH. $\alpha$-Interferon therapy of chronic hepatitis B Current status and recommendations. $\mathcal{F}$ Hepatol 1990; 11 : S100-7.

13 Lok ASF, Lai CL, Wu PC, Leung EKY. Long-term follow-up in a randomised controlled trial of recombinant alpha- 2 interferon in Chinese patients with chronic hepatitis B infection. Lancet 1988; ii: 298-302.

14 Thomas HC. The hepatitis B virus and the host response. 7 Hepatol 1990; 11: S83-9.

15 Fattovich G, Brollo L, Boscaro S, Pontisso P, Giustina G, et al. Long-term effect of low dose recombinant interferon therapy in patients with chronic hepatitis B F Hepatol 1989; 9: 331-7.

16 Saracco G, Mazzella G, Rosina F, Cancellieri C, Lattore V, et al. A controlled trial of human lymphoblastoid interferon in chronic hepatitis B in Italy. Hepatology 1989; 10: 336-11.

17 Carreno V, Porres JC, Mora I, Bartolome J, Bas C, et al. Prolonged (6 months) treatment of chronic hepatitis B virus infection with recombinant leukocyte $A$ interferon. Liver 1987; 7: 325-32.

18 Alexander GJM, Brahm J, Fagan EA, Smith HM, Daniels HM, Eddleston ALWF, et al. Loss of HBsAg with interferon therapy in chronic hepatitis B virus infection. Lancet 1987; ii: 66-9.

19 Scully LJ, Shein R, Karayiannis P, McDonald JA, Thoma HC. Lymphoblastoid interferon therapy of chronic hepatitis $\mathrm{HBV}$ infection. A comparison of $12 v 24$ weeks of thrice weekly treatment. $\mathcal{F}$ Hepatol 1987 ; 5: 51-8. 